\title{
Occupational Therapy Practice in Egypt: Cultural Perspective
}

\author{
Mohannad Amireh* \\ Launch Egypt Center, Cairo, Egypt \\ Submission: December 20, 2018; Published: January 09, 2019 \\ *Corresponding author: Mohannad Amireh, Launch Egypt Center, Maadi, Cairo, Egypt
}

\section{Occupational Therapy}

Occupational therapy is a rehabilitation profession that concerns with assess, assign plan, and intervening persons with special needs. It is based on occupation of people, which includes seven areas; activity of daily living, instrumental activity of daily living, work, education, play, leisure, and social participation. According to World federation of occupational therapy, occupational therapy can be defined as "a client-centered health profession concerned with promoting health and well-being through occupation. The primary goal of occupational therapy is to enable people to participate in the activities of everyday life. Occupational therapists achieve this outcome by working with people and communities to enhance their ability to engage in the occupations they want to, need to, or are expected to do, or by modifying the occupation or the environment to better support their occupational engagement" [1].

In the era of globalization, occupational therapists travel and work in different countries, and communicate with people who have different perceptions, rituals, ideas, and thoughts. These therapists need to be culturally sensitive when dealing with native people or other minorities. Studying culture is a primary goal of any successful expatriate therapist. Human resource departments in global organizations is responsible to learn expatriate healthcare professionals about culture of the host country. I still remember that when I travelled to work in Saudi Arabia, the organization held a lecture about "Saudi Arabian culture". Also, an important practice of human resource department is to help expatriate professionals to repatriate when they go back to their home country.

The concern of studying the Egyptian culture by occupational therapists reaches its maximum level when we know that Egyptian universities do not offer occupational therapy programs, and therefore the Egyptian market provide a big opportunity for other nationalities to practice occupational therapy in Egypt.

\section{Culture}

Culture is "the collective programming of the mind that distinguishes the members of one group or category of people from others"[2]. Hofstede introduced his model of studying culture, which included six dimensions:

Power Distance: The dimension that illustrated the extent of accepting and expecting unequal power distribution in the different institutions of a society.

Uncertainty Avoidance: The dimension that revealed the level of stress in a society in the face of an ambiguity and unstructured situation.

Individualism: The dimension that illustrated the level of intellectual independence from the primary groups.

Masculinity: The dimension that detected the gap of different roles between women and men in a society.

Long Term Orientation: The dimension that discovered the time which people in a society directing their efforts: present or future.

Indulgence: The dimension that revealed the level of demonstrating enjoying life and having fun.

Each dimension has a measure started from 0 and ended at 100. Each culture had a degree on all measures. The measure did not give superiority for countries on others, as high score did not indicate better results, but it simply showed different characteristics. This article focused on the fifth dimension, long term orientation. I selected this dimension to discuss because the Egyptian culture scored the lowest in the world on its measure [3]. I discussed long-term orientation in Egypt in my book, culture and management, and I assumed that the low degree of long-term orientation among contemporary Egyptians was due to their deep-rooted ancient civilization [4].

\section{Long-Term Orientation}

The primary characteristic of people in short-term oriented cultures, who scored low on the dimension of long-term orientation, that they expect immediate outcomes, and do not plan for long run goals. One of my clients was 7 years old. He was diagnosed with autism and came with his parents to occupational therapy department to start a rehabilitation program. I 
evaluated him and interviewed his parents. The parents stated that they expected for him to be independent in eating, dressing, and grooming. They indicated that they changed three places in one year because they did not see improvement in their child's abilities. The child had vestibular, proprioceptive, and auditory challenges that affected directly motor planning. Training for activity of daily living was not a reliable goal. He supposed to engage in sensory integration program as foundation to improve motor planning.

Caregivers looked for quick results and expected that their children's goals would be achieved quickly. They would frustrate easily and loosed their motivation if they did not see quick improvement or if the therapist stated that he did not have immediate solutions for their children's challenges. The caregivers needed to know that rehabilitation was long-life process, and it was better to work with a therapist for longtime than finding another who could achieve quick results.

The characteristic of not considering long term goals gives low value for persistent. People do not need to learn how to be patient and hard workers if they do not have long-term goals. One child came to occupational therapy department with a concern of improving dynamic tripod grasp. After two weeks, his father explained to me that he would come one time per week instead of three because of his busy schedule. Later, the father asked to have occupational therapy sessions in his home instead of the center because he lived far. The center's policy did not allow this. The father stopped to come after one month even the child had big improvement, and it was explained to the father that the child might need just another month.

Therapist needed to convince caregivers that driving in rush and spending long time is easier than challenges that would encounter them if they terminated rehabilitation programs. In short-term oriented cultures, traditionalism drives ideas of people. There are inherited rules that are not supposed to be broken. Personal steadiness and stability is perceived a good value. Changing values, rules, customs, and mores depending on situations is not desired.

I remember that parents of one of my clients asked me to enforce him to use his right hand in different activities, especially eating. I explained to them that most of people are right-handed, but $8-15 \%$ of people are left-handed, and their child belonged to the latter. In general, there were many effects of changing the dominant hand, such as; bed-wetting, stuttering, nail biting, shyness and being withdrawn, defiance and provocative behavior, poor concentration, bad memory, reading difficulties, problems with spelling, neurotic personality, and physical tiredness. The caregivers argued that the child should respect the traditions of the society, or he would be a subject of gossip.

The caregivers had strong relationship with past. Everything coming from past was perceived better, and this included behavior. The caregivers had social obligations and needed to protect their 'face'. Therapists should respect the tendency of people to be steady and had personalities that were harmonious with their old roots. Also, therapists needed to know the high value of protecting face and avoiding scandals of breaking traditions. Expatriates who deal with people belonging to another culture are supposed to be culturally-sensitive. Longterm orientation is an important dimension of culture. Many behaviors of people can be interpreted based on knowledge about this dimension.

\section{References}

1. About occupational therapy (2018) World Federation of Occupational Therapists.

2. Hofstede G (2011) Dimensionalizing cultures: The Hofstede model in context. Online readings in psychology and culture 2(1).

3. Country Comparison (2018) Hofstede Insights.

4. Amireh M (2018) Culture and management. Lambert Academic Publishing: Saarbrücken, Germany.

\section{Your next submission with Juniper Publishers will reach you the below assets}

- Quality Editorial service

- Swift Peer Review

- Reprints availability

- E-prints Service

- Manuscript Podcast for convenient understanding

- Global attainment for your research

- Manuscript accessibility in different formats

( Pdf, E-pub, Full Text, Audio)

- Unceasing customer service

Track the below URL for one-step submission

https://juniperpublishers.com/online-submission.php 